\title{
Evaluation of the Quality of Occupational Therapy Fieldwork Experiences
}

\author{
Donna Patricia Drynan* \\ University of British Columbia, Canada \\ Jennifer Ann Turnbull \\ Med Travelers, United States \\ Leanne M. Currie \\ University of British Columbia, Canada
}

\begin{abstract}
Practice education, or fieldwork as it is referred to in occupational therapy, is a fundamental feature of occupational therapy education, priming students to become competent entry-level practitioners. Factors reported as contributing to poor quality fieldwork experiences include: students not receiving enough feedback; lack of opportunity to develop skills; and not being made to feel welcome in the environment. These are significant contributors to the overall development of competence so it is important to understand the current context of fieldwork experiences being offered in relation to the notion of quality in those learning environments. The purpose of this study was to evaluate the quality of the fieldwork learning environment from the perspective of occupational therapists' working in one region of Canada. A validated survey, the Quality of Occupational Therapy Fieldwork Experience (QOTFE) tool, was used to identify features of what might constitute quality fieldwork education, and to determine whether there was a difference in quality of fieldwork experience between practice settings or types of practice areas. However, there was minimal variability in scores based on practice setting and practice area variables. These findings indicate a consistent quality of fieldwork experience across practice settings and practice areas. This research presents a picture of the current quality of fieldwork experiences available to occupational therapy students. This may be a starting place for further investigation into the factors that contribute to the quality of practice education learning experiences
\end{abstract}

Keywords: fieldwork quality; occupational therapy; practice education

${ }^{\star}$ Corresponding Author: Donna Drynan, M.Ed., OT(C), Senior Instructor and Academic Fieldwork Coordinator, Dept of Occupational Science \& Occupational Therapy, Faculty of Medicine, UBC T325-2211 Wesbrook Mall, Vancouver, BC V6T 2B5 Canada

Email: donna.drynan@ubc.ca

Journal URL: http://e-learning.coventry.ac.uk/ojs/index.php/pblh

Drynan, D.P., Turnbull, J.A., and Currie, L.M. (2018) 'Evaluation of the quality of occupational therapy fieldwork experiences'. International Journal of Practice-based Learning in Health and Social Care, 6 (2), 48-63 


\section{๑๐ఠ0} Access article is distributed under the terms of the Creative Commons Attribution Attribution-Non-

Commercial No Derivatives 4.0 International License (https://creativecommons.org/licenses/by-nc-nd/4.0/ ), which permits unrestricted non-commercial use, distribution, and reproduction in any medium, provided the original work is properly cited and is unaltered. 


\section{Introduction}

Occupational therapy (OT) fieldwork education provides students with the opportunity to gain a breadth of practical learning experience across various practice settings. Through use of available structured learning opportunities, fieldwork education enables students to integrate theory with practice, build confidence and develop the professional skills, attitudes and behaviours required of a registered safe and effective practitioner (CAOT [Canadian Association of Occupational Therapists] 2012, Sloggett, Kim, and Cameron 2003). It has been reported that fieldwork experiences deemed to be of low quality have been shown to impact students negatively (Hall, McFarlane, and Mulholland 2012, Mulholland and Hall 2013, Thomson, Docherty, and Duffy 2017). Offerings for occupational therapy fieldwork education have been reported not always to be consistent in Canada (personal communication, 18 April 2016, Committee of University Fieldwork Educators) and therefore some students may feel they have received less than optimal practice-based experiences. Most of the issues reported as contributing to low quality include: not getting the opportunity to develop essential skills; being dismissed for trying to be proactive; and reporting that feedback was lacking (Rodger et al. 2011, Thomson, Docherty, and Duffy 2017). In an era in which post-secondary institutions are frequently trying to increase fieldwork placement capacity to meet the increasing enrolment, often the quality of the experiences are overlooked in order to ensure sufficient placements (Taylor et al. 2016). Despite the need for quality fieldwork experiences, research on this topic has not identified indicators in occupational therapy from the perspective of the fieldwork educator. Additionally, there is not yet a standardised measurement tool available for evaluation of fieldwork education quality. In order to address this gap, an evaluation was conducted with occupational therapists using self-completed questionnaires to identify: 1) what is the current quality of occupational therapy fieldwork education?; and 2) is there a difference in quality of fieldwork experience between practice settings or types of practice areas? This study was located in British Columbia, Canada.

\section{Background}

In order to meet graduation requirements, all occupational therapy students in Canada must complete 1,000 hours of fieldwork education as per the World Federation of Occupational Therapists (WFOT) standard (CAOT [Canadian Association of Occupational Therapists] 2012, WFOT [World Federation of Occupational Therapists] 2016). Fieldwork education is an essential component of the curriculum that provides students with the knowledge, skills and behaviours for future practice within the discipline of occupational therapy. Fieldwork education gives exposure not only to the culture of the profession, it also promotes the development of clinical reasoning skills and allows students the opportunity to develop technical skills (e.g. measuring wheelchairs, running groups) used in OT practice through the provision of appropriate opportunities to develop interventions with a wide range of clients (Rodger et al. 2011). Fieldwork educators are those individuals who have agreed to supervise students within their work setting; they are not employed by the university, so it could be assumed that the quality of teaching provided by the numerous fieldwork educators would be highly variable. Although sessions to prepare preceptors in various professions are offered by universities, these are not necessarily mandatory nor are they offered at times accessible to all those who will be hosting students. The benefits of high quality fieldwork education have been demonstrated to extend beyond the student to the fieldwork educators, the fieldwork education sites and the practice areas. Sloggett, Kim, and Cameron (2003) report that fieldwork educators list opportunity for later recruitment, a sense of contributing to the profession, and the development of their own clinical reasoning and time-management skills as some of the benefits of providing student fieldwork education. Additional benefits to the educator include: a reduction in employee workload; improved ability to 'stay connected' with educational institutions; student promotion of the occupational therapy role; and the ability to run larger client group programs. In addition, to quote the American Occupational Therapy Association, "The value of fieldwork transcends the obvious benefits directed toward the student. Supervising students enhances fieldwork educators' own professional development by providing exposure to current practice 
trends, evidence-based practice, and research" (American Occupational Therapy Association 2009: 1).

Practice settings and practice areas can benefit from providing high-quality occupational therapy fieldwork education by enhancing their ability to recruit students after graduation (Thomas et al. 2007). Further, fieldwork experience has been consistently reported to have the highest influence on students' development of preference for a specific practice area and geographical locations (Sloggett, Kim, and Cameron 2003). Fieldwork placements may also make graduation recruitment more efficient as student capabilities and prospective employers can assess work characteristics during fieldwork (CAOT [Canadian Association of Occupational Therapists] 2012, Thomas et al. 2007).

Current occupational therapy literature has explored the essential elements that contribute to overall quality of fieldwork from both the students' and educators' perspectives. Research has identified: (1) positive learning environments; (2) regular and constructive feedback; (3) an approachable educator; (4) open student-educator communication; (5) diverse learning opportunities; and (6) a balance between supervision and independent learning, as factors that were important to both groups (Bonello 2001, Hummell 1997, Mullholland and Hall 2013, Rodger et al. 2011). Research specific to the fieldwork educator perspective has emphasised the importance of regular professional development opportunities for the fieldwork supervisor, and open communication of university curriculum as two factors that are critical to fieldwork quality (Kirke, Layton, and Sim 2007).

The Canadian Guidelines for Fieldwork Education in Occupational Therapy (CGFEOT) is a document that has been developed to direct fieldwork partners (students, fieldwork educators and university fieldwork coordinators) in developing an effective environment for learning. The CGFEOT is a national guideline that identifies the responsibilities of the main fieldwork education partners, establishes the principles guiding fieldwork education, and reflects current best practice in determining optimal conditions for fieldwork education (CAOT [Canadian Association of Occupational Therapists] 2012). In conjunction with current literature, the CGFEOT can be used to guide an evaluation of fieldwork quality in British Columbia.

Fieldwork quality has been extensively studied in nursing and medicine. Currie and colleagues created and validated a 27-item questionnaire that measures the Quality of Clinical Learning Environment (QCLE) according to a nursing perspective (Currie et al. 2015). Their study surveyed clinical nurses $(n=584)$, students $(n=804)$, and teachers $(n=96)$, to examine the relationship between number of student hours hosted in a clinical setting, readiness for student practice education, and the quality of clinical learning environment of clinical settings. The QCLE tool was validated using confirmatory factor analysis that identified four factors, which had a significant chi-square value $(X 2(318, n=740)=1222.486, p<0.001)$. The researchers found that most clinical settings that hosted students had a high quality of learning environment (3.27 out of $5, S D=0.17$ ) and that the quality of the learning environment was higher in units where the manager was overseeing fewer clinical settings $(p=0.027)$.

The role of the fieldwork educator has been identified for many years as the most critical component of the fieldwork experience (Christie, Joyce, and Moeller 1985). Fieldwork educators can facilitate optimal learning environments by promoting the development of students' practice knowledge, skills, behaviours, attitudes and professional competencies. The fieldwork educator further impacts the learning environment as a result of their ability to model professional practice behaviours, guide student practice within the setting, and provide formal and informal feedback regarding student performance and development (Mullholland, Derdall, and Roy 2006). Enhancing fieldwork education quality may encourage educators to offer a greater number of fieldwork education opportunities. Therefore, this study was designed to evaluate fieldwork quality from the perspective of the fieldwork educator. 


\section{Methods}

\section{Ethics}

Prior to conducting the study, ethics approval was obtained from the University of British Columbia Behavioural Research Ethics Board, study ID H15-01979.

\section{Population and sampling}

Demographic data elements were identified from the Canadian Institute for Health Information: Occupational Therapist Database ( $\mathrm{ClHI} 2013)$ which includes gender, age, type of degree. In addition, data elements from the Provincial Regulatory College including geographic work location, area of practice and years of experience were included. Convenience sampling was used to identify participants who would increase the understanding of the research topic, and meet predetermined inclusion criteria. Inclusion criteria required that participants were registered occupational therapists and had provided consent to be contacted for research purposes on their college registration form.

The questionnaire was emailed to 1,501 occupational therapists that were registered with the Regulatory College of Occupational Therapists in the targeted region and had given consent to be contacted.

\section{Questionnaire}

A web-based questionnaire entitled the Quality of Occupational Therapy Fieldwork Experience (QOTFE), consisted of 26 questions and was designed to measure the quality of fieldwork learning experiences from the perspective of fieldwork educators. The QCLE authors granted permission to adapt the survey (survey available at http://www.msfhr.org/placements-learnersassessing-capacity-and-effectiveness-clinical-sites-places-study). A total of 21 questions from the QCLE were adjusted to reflect occupational therapy terminology and the fieldwork context while maintaining the same meaning (e.g., the words 'clinical teacher', used in nursing to denote the person directly supervising the student clinical, was replaced with the word 'fieldwork educator'). Five questions remained unchanged. The QOTFE survey questions were divided into 4 sections addressing: 1) Role of Fieldwork Educator in Student Learning; (2) Role of the Practice Environment and Team in Student Learning; (3) Manager's Contribution to Student Learning; and (4) Preparation of the Student for Fieldwork Education. These sections were consistent with the 4 factors identified by the confirmatory factor analysis conducted by $\underline{\text { Currie et }}$ al. (2015). Consistent with the QCLE questionnaire, participants were asked to respond to each question on a 5-point Likert scale ranging from strongly disagree to strongly agree. A Likert score of 1 represented a low quality rating, while a score of 5 represented high quality. Participants were given the option of responding 'Not Applicable' for all questions. The survey included a list of definitions for key terminology to facilitate respondent comprehension.

\section{Pilot study}

A small pilot study was conducted in order to assess the face validity of the QOTFE questionnaire with the intention of addressing any questions that were not suitable according to the participants. This pilot study included six purposively sampled occupational therapists who consistently supervise students. The questionnaire and consent link were emailed to the pilot survey participants, who were additionally asked to complete a form to gather their opinions on: clarity of questions, terminology and instructions; and ease of technology platform. Participants indicated that the survey questions were appropriate, the instructions were clear and the survey terminology was consistent with their experiences in supervising student occupational therapists (see Appendix A for the survey questions). No changes were made to the final questionnaire based on the pilot survey feedback. 


\section{Data collection and management}

Contact was made using the modified Dillman procedure (Dillman, Smyth, and Christian 2014), which included five emails over the course of five weeks (i. awareness of study email; ii-iv. invitation to participate 1, 2, 3; and v. thank you email) during the months of January and February 2016. Participants completed the questionnaire online via Fluid Survey ${ }^{\mathrm{TM}}$, which at the time was a secure Canada-based survey company, which complied with Canadian research and data storage laws.

\section{Data analysis}

The Statistical Package for the Social Sciences (IBM SPSS ${ }^{\circledR}$ ) version 24 was used to analyse the data. Frequency tables and descriptive statistics were used to describe the groups within the sample. ANOVAs were carried out with the predictor variables of target population and practice setting to compare mean survey scores. A significance level of $p=0.05$ was used as the alpha level for all tests. Sub-analyses were performed by looking at differences in scores based on 7 different practice settings, 6 different target populations, and the 4 sub-domains of the survey.

\section{Results}

\section{Participants}

A total of 157 occupational therapists (target sample $N=1,501$ ) completed the questionnaire giving an $11 \%$ response rate. There was a higher proportion of female participants $(n=143$;

Table 1: Summary of participant demographics

\begin{tabular}{|c|c|}
\hline Participant Demographics & $N=157(\%)$ \\
\hline \multicolumn{2}{|l|}{ Type of Student Supervisory Models } \\
\hline Student Lead Clinic (More than 2 students) & $8(5.1)$ \\
\hline 1:1 (OT: Student) & $107(68.2)$ \\
\hline 1:2 (OT: Student) & $5(3.2)$ \\
\hline 2:1 (OT: Student) & $28(17.8)$ \\
\hline No Student & $4(2.5)$ \\
\hline Other & $5(3.2)$ \\
\hline \multicolumn{2}{|l|}{ Practice Setting } \\
\hline General Hospital & $42(26.8)$ \\
\hline Rehabilitation Facility & $26(16.6)$ \\
\hline Mental Health Facility & $8(5.1)$ \\
\hline Residential Care & $11(7.0)$ \\
\hline Community Health Centre & $36(22.9)$ \\
\hline Other & $34(21.7)$ \\
\hline \multicolumn{2}{|l|}{ Practice Area } \\
\hline Mental Health & 36 (22.9) \\
\hline Neurological System & $24(15.3)$ \\
\hline Musculoskeletal System & $9(5.7)$ \\
\hline General Physical Health & $48(30.6)$ \\
\hline Other Areas of District Service & $21(13.4)$ \\
\hline Other Areas of Practice & $19(12.1)$ \\
\hline \multicolumn{2}{|l|}{ Employment Complement } \\
\hline Regular Full Time & $102(65.0)$ \\
\hline Temporary Full Time & 3 (1.9) \\
\hline Temporary Part Time & $4(2.5)$ \\
\hline Regular Part Time & $44(28.0)$ \\
\hline Casual & $4(2.5)$ \\
\hline \multicolumn{2}{|l|}{ Sex } \\
\hline Female & 143 (91.1) \\
\hline Male & 13 (8.3) \\
\hline Other & $1(0.6)$ \\
\hline
\end{tabular}


91.1\%) than males ( $n=13 ; 8.3 \%$ ) The mean age of participants was 43 years (range 28-67; SD $=9.5$ ). Overall, the group consisted of very experienced participants who had been practising as occupational therapists for a mean of 16 years $(S D=9.9)$ and had been employed in their current practice setting for a mean of 9.5 years $(S D=7.1)$. The majority of respondents were working full-time. Most identified as working in a General Hospital, Community Health Centre and 'Other' practice settings such as Assisted Living Facilities, School-Based Settings and Private Practice Settings, while fewer respondents identified working in a Mental Health practice setting. Most respondents practised with general physical health populations. The lowest response rate was from respondents practising with musculoskeletal populations. Table 1 gives a summary of our participant demographics.

\section{Practice setting}

In comparing means across practice settings, it was noted that the lowest perception of fieldwork education quality was from practitioners working within Mental Health practice settings $(M=4.04, S D=0.49)$. The highest perception of fieldwork education quality was from practitioners working within 'Other practice settings' $(M=4.36, S D=0.46)$. These mean scores are illustrated in Figure 1. Overall, there appeared to be little difference between the quality scores across groups. In order to examine if there were significant differences in scores based on practice setting, a one-way ANOVA was performed with a predictor of practice setting and a dependent variable of mean survey score $(F=0.599, p=0.731)$. There was no statistically significant difference in the mean scores based on practice setting at the $p<.05$ level. This showed that there is minimal variability in the quality of learning environment based on the practice setting.

Figure 1: Mean QOTFE scores by practice setting

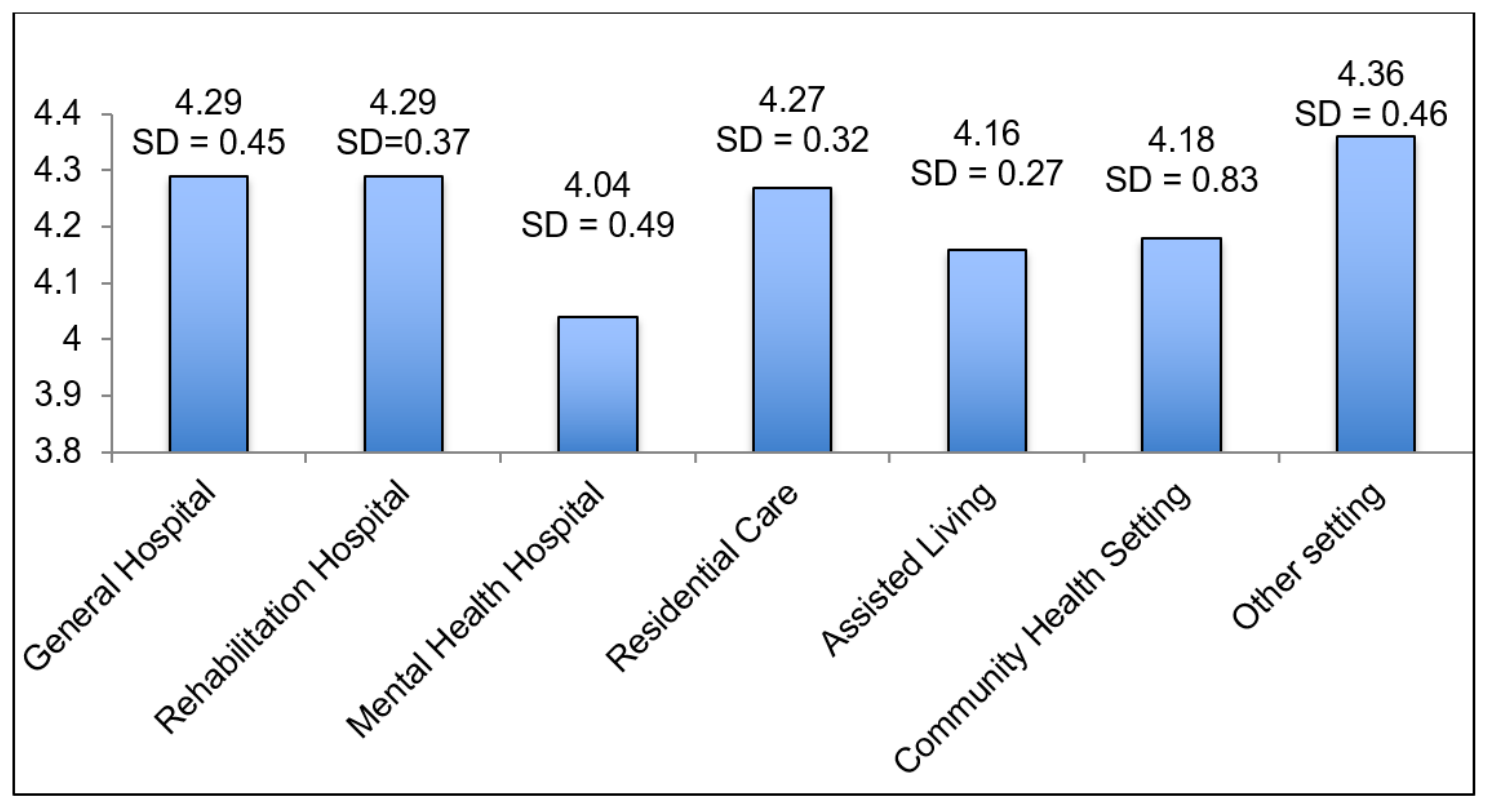

Means scores of fieldwork quality were calculated across eight different practice areas. It was noted that the highest perceptions of fieldwork education quality were from practitioners working with musculoskeletal populations $(M=4.58, S D=0.28)$ while the lowest perceptions of quality were from educators working in direct service $(M=4.17, S D=1.05)$. No survey responses were obtained from educators working with cardiovascular/respiratory health or digestive/endocrine health populations. There appeared to be little difference between the quality scores of these groups. These means scores are illustrated in Figure 2. A one-way ANOVA was performed with a predictor of practice area and a dependent variable of mean survey score $(F=1.03, p=0.41)$ indicating that there was no statistically significant difference in the mean scores based on 
practice area. This demonstrated that there is minimal variability in the quality of learning environment based on practice area.

Figure 2: Mean QOTFE score by practice area

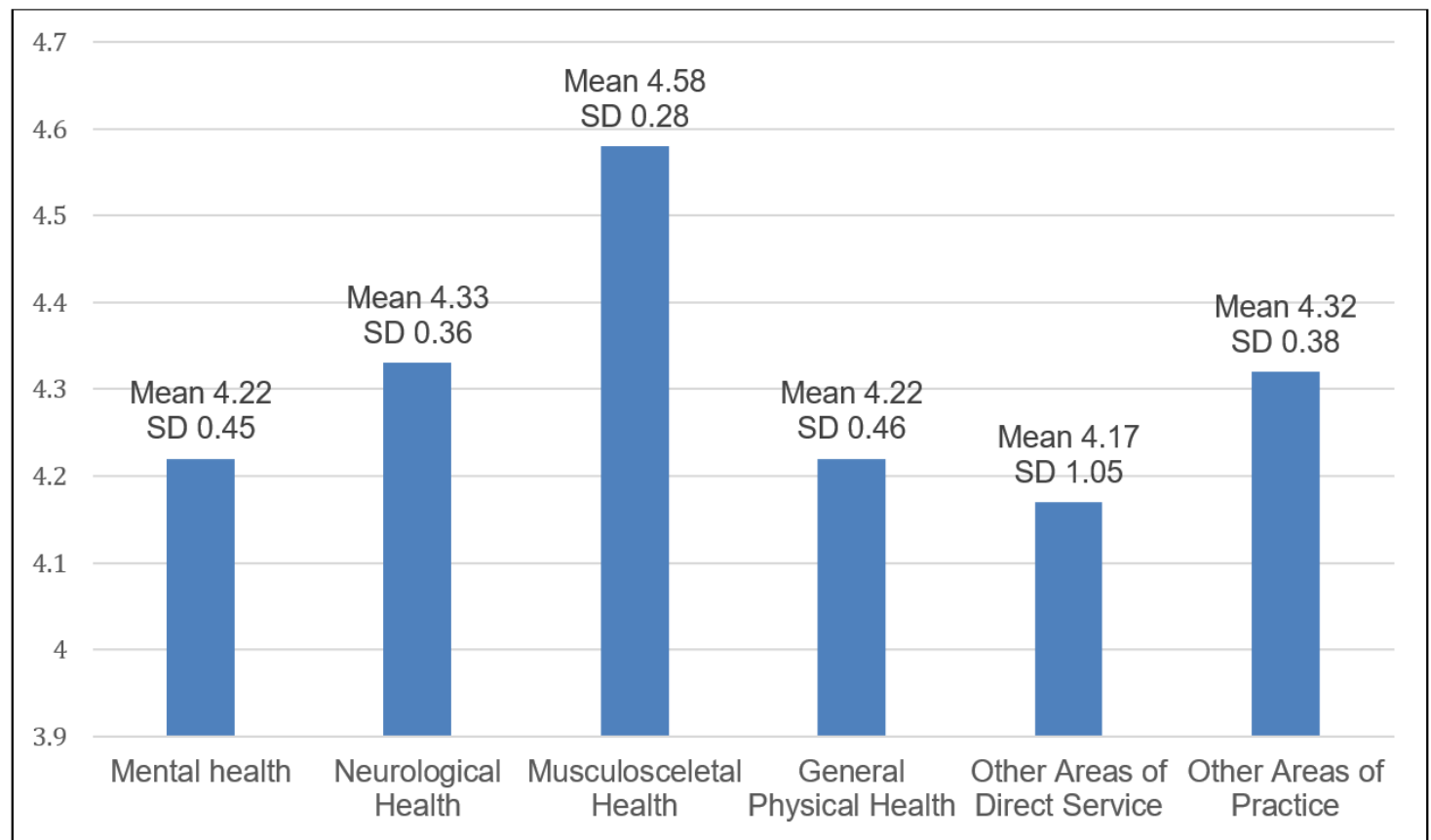

\section{QOTFE Survey Subdomains}

\section{Role of fieldwork educator in student learning}

Notably, participants are responding about their own practice towards students so it was expected that the highest mean score values were calculated within the Role of Fieldwork Educator in Student Learning domain $(M=4.47, S D=0.73)$. High proportions of fieldwork educators reported that they supported student learning through the use of multiple teaching strategies (91.8\%), encouraged more independence as the students skills increased (96.1\%), informed students of possible learning opportunities (95.1\%) and were easily approachable (94.1\%). What's more, 95.6\% of the participants felt they acted as positive role models for occupational therapy. With regard to feedback, $67.5 \%$ strongly agreed and $29.6 \%$ agreed that their feedback contributed to student learning.

\section{Role of practice environment and team in student learning}

The second highest mean score was calculated for the section Role of the Practice Environment and Team in Student Learning $(M=4.31, S D=0.46)$. The majority of educators reported that students were made to feel comfortable before starting a shift (93.2\%) and felt that the learning environment was positive (93.2\%). Moreover, $81.4 \%$ of respondents felt that there was a strong spirit of solidarity amongst their practice team.

\section{Manager's contribution to student learning}

The Manager's Contribution to Student Learning domain had the second lowest overall mean score $(M=4.00, S D=0.73)$. Of interest, $38.8 \%$ of respondents agreed and $45.1 \%$ strongly agreed that the manager was supportive of their role as fieldwork educators. Most respondents felt that their manager regarded them as a key resource within the practice team. However, only $54.9 \%$ of all respondents agreed or strongly agreed that the manager was a team member. 
Nearly $65 \%$ of respondents agree $(42.2 \%)$ or strongly agree $(24.8 \%)$ that the manager appreciated their individual efforts.

\section{Preparation of the student for fieldwork education}

The lowest mean score was shown in the Preparation for Student Fieldwork Education domain $(M=3.85, S D=0.66)$. It was noted that $39.9 \%$ of educators agreed and $49.8 \%$ strongly agreed that they had the opportunity to attend preceptor training sessions. While $51 \%$ of educators agreed and $22.3 \%$ strongly agreed that there was a well-defined communication process between themselves and the university, just under half were not aware of students' learning objectives before their students arrived (44.4\%). The means scores of all sub domains can be viewed in Figure 3.

Figure 3: Mean QOTFE scores by sub domain

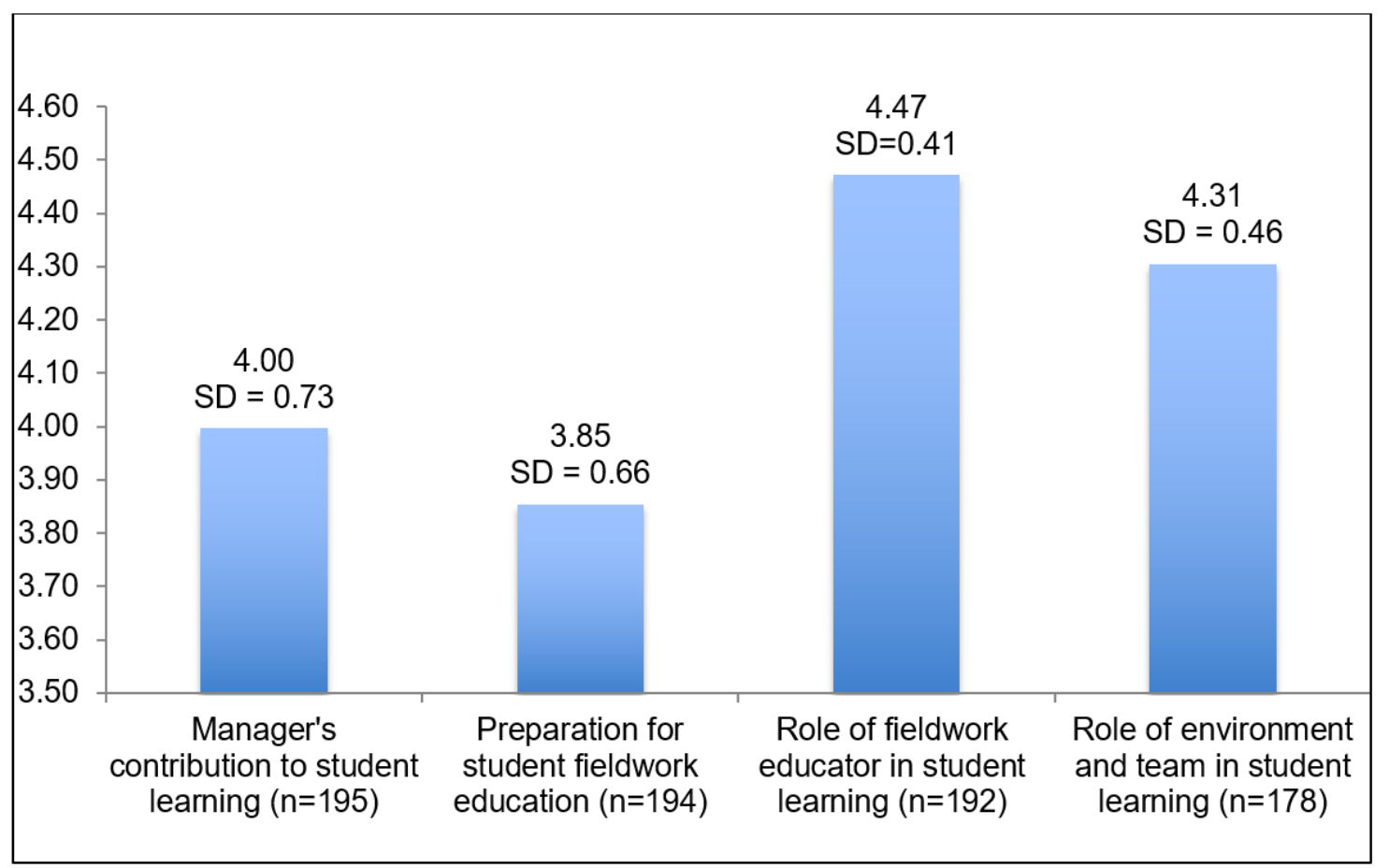

\section{Discussion}

Overall, educators' ratings of fieldwork quality were high. There was minimal variability in scores based on practice setting and practice area variables. These findings indicate a consistent quality of fieldwork experience across practice settings and practice areas. Therefore students are likely to receive high quality learning experiences regardless of where they are placed during their fieldwork education. The similarity in quality of fieldwork education between practice settings and practice areas may, in part, be due to the development of standardised policy and procedures. The CGFEOT national guidelines have been developed to maintain and enhance the quality of the fieldwork experience. This document identifies the responsibilities of the main fieldwork education partners, establishes the principles guiding fieldwork education, and reflects current best practice in determining optimal conditions for fieldwork education. The CGFEOT specifies that educators should: prepare to mentor students by familiarising themselves with the fieldwork education program; provide a welcoming learning environment; act as positive role models for students; and offer regular and timely feedback. We found that high educator responses were reflected in questions that addressed each of these CGFEOT guidelines. 
Most educators stated that they provided students with regular feedback. The provision of regular, balanced and constructive feedback is described by several authors (Kirke, Layton, and Sim 2007, Thomas et al. 2007, Thomson, Docherty, and Duffy 2017) as necessary for effective student learning. Fieldwork educators reported being approachable, showing interest in student learning, and making an effort to get to know their students. Approachability and friendly communication have been found to be supportive of students' learning (Bonello 2001, Ford et al. 2016, Kirke, Layton, and Sim 2007). Educators indicated that they encouraged independence as their students' skills increased, and supported student learning through the use of various teaching strategies such as weekly reflections, and practical learning. The importance of these factors in facilitating student learning and reflection has been previously identified in the literature (Rodger et al. 2011). Our findings, in conjunction with the literature, demonstrate the overall positive impact of the educator on the quality of fieldwork learning. While the educators' high self-ratings might be expected, future research gaining perspectives, such as the study by Currie et al. (2015), might provide a more accurate score. Also, it may be possible that the questionnaire could encourage fieldwork educators to attend to areas where they gave lower self-ratings.

Educators reported that students were encouraged to take part in patient care rounds, and were made to feel comfortable before starting each shift. They stated that an overall positive learning environment was created when students were on site. A positive and welcoming learning environment has been shown to be conducive to quality learning experiences and future recruitment (Bonello 2001, Kirke, Layton, and Sim 2007). Our findings support the notion that an overall positive learning environment is contributing to the quality of fieldwork across fieldwork sites.

The majority of our respondents felt that managers regarded their staff as a key resource. Previous nursing studies have identified that the learning environment is significantly more positive when the manager values the knowledge and opinions of staff (Skaalvik, Normann, and Henriksen 2011). Moreover, the majority of respondents felt that the manager was supportive of those in the role of fieldwork educator. Nursing literature has stated that supportive management is important to the quality of the clinical learning environment (Skaalvik, Normann, and Henriksen 2011). Our survey findings, in conjunction with the literature, suggest that the quality of the learning environment is enhanced when managers support their staff and value them as a resource. Conversely, 35.9\% of respondents did not view the manager as a team member. Research has identified that the learning environment is significantly more positive when the manager is an active member of the clinical team (Skaalvik, Normann, and Henriksen 2011). Previous nursing studies have found that the quality of clinical learning environments are more favourable where managers oversaw fewer practice settings overall, suggesting that the consistent presence of a manager can positively impact the quality of clinical practice education in nursing (Currie et al. 2015). We did not explore whether or not managers were overseeing many departments in our study. Furthermore, there was wide variability in quality ratings found in the category 'Manager's Contribution to Student Learning'. Given that the evidence suggests that the manager is important in determining the quality of fieldwork education, it is recommended that future research examines the role of the manager in the occupational therapy fieldwork experience in more detail. This may inform the development of strategies aimed at enhancing the manager's contribution to student learning. It is also possible that the variability in survey findings may be due to confusion surrounding the term 'manager'. While this term is commonly used in nursing clinical education, and was used throughout the QCLE survey (Currie et al. 2015), it is possible that 'manager' does not reflect terminology commonly used in occupational therapy practice. Therefore this term may have been misleading for participants. Future versions of the survey may consider the use of terms such as 'student liaison' or 'practice lead'.

Our findings suggest that fieldwork educators are prepared by the university to facilitate highquality fieldwork experiences. The majority of educators reported that they had the opportunity to attend preceptor and mentor training. The majority of educators also reported that there was a well-defined communication process between fieldwork educators and the university. The 
literature has emphasised the importance of regular professional development opportunities and open communication of university curriculum as factors that are critical to fieldwork quality, as they contribute to educator competence (Kirk, Layton, and Sim 2007). Our findings suggest that the local university's ability to adequately prepare fieldwork educators for student learning may have contributed to high quality fieldwork education. While the majority of fieldwork educators reported being aware of their students' learning objectives, $43.4 \%$ reported that they had not received them prior to the students' arrival. Low ratings for this question may have resulted in the preparation category receiving the lowest overall ratings of the 4 domains. These findings suggest the need for policies and procedures to be developed that require students to submit their learning objectives by a predetermined date deemed suitable by the educators and universities. Further studies may investigate methods for improving the development of student learning objectives.

\section{Limitations}

Limitations of this study must be acknowledged. We obtained a low overall response rate of $11 \%$ and therefore limit the possible interpretations. Future studies should consider the use of incentive methods in order to increase the number of respondents. This could include a small compensation for survey completion. Additionally, future researchers may improve response rates by distributing a paper-based survey in addition to the email version. A greater number of respondents would allow for factor-analysis to be performed on survey results. This would allow validation of the QOTFE as a survey tool. As this was a self-administered questionnaire, responses may not be an accurate representation of actual opinions, and the possibility of social desirability bias should be considered (for example, social desirability bias may have influenced the fieldwork educators' high self-ratings). Furthermore, no survey responses were obtained from educators working with cardiovascular/respiratory health or digestive/endocrine health populations. This may indicate a sample bias leading to lack of a fully representative sample. Future studies may benefit from obtaining data from participants who are inclusive of these populations. Alternatively they may explore whether this target population category may not be relevant to occupational therapy practitioners. Open-ended responses were not analysed in this study due to time constraints for the study team; a future study could explore the qualitative responses. Information collected through qualitative methods may help to identify factors affecting quality that were not mentioned in the QOTFE survey. Additionally, the qualitative data may pinpoint factors that could improve the fieldwork educators' ability to create quality learning experiences. Future studies would benefit from seeking out the opinion of student occupational therapists. This would provide a more comprehensive picture of the fieldwork experience. Additional studies may expand upon these findings through the creation of a national survey, seeking leadership, student and preceptor opinion on the current quality of fieldwork.

\section{Conclusion}

This study has explored the current quality of occupational therapy fieldwork experiences according to fieldwork educators practising in British Columbia in Canada. A web-based survey instrument, the Quality of Occupational Therapy Fieldwork Education questionnaire, was created in order to gather these results. Survey findings have demonstrated consistency of high quality experiences across fieldwork settings and target populations. They have shown that fieldwork educators utilise diverse learning strategies, provide regular feedback, and allow students independence, suggesting adherence to the Canadian Guidelines for Fieldwork Education in Occupational Therapy. Overall, fieldwork-learning environments are shown to be positive and to make students feel comfortable. According to the literature, these factors contribute to high quality learning experiences. Occupational therapy fieldwork managers supported educators and treated them as a key resource. A trend in results showed that managers may not have been integrated into the practice team. Regular communication with the university and the opportunity to attend training workshops were reported. Literature has 
shown that these factors increase the quality of the fieldwork learning experience. Educators were not always provided with student learning objectives prior to arrival, which may have affected educator preparation. Overall, our findings have demonstrated high quality occupational therapy fieldwork learning experiences across the province. Ultimately these findings may be viewed as an opportunity for drawing into the light some areas contributing to quality and possible areas for improvement. Future studies may find the QOTFE questionnaire useful for assessing fieldwork education quality in other provinces or on a Canadian national level.

\section{Acknowledgements}

The authors would like to thank all of the OTs who participated in the study. We would also like to thank and acknowledge Kendra Nimmo for her contributions to the project. 


\section{References}

American Occupational Therapy Association. (2009) 'Occupational therapy fieldwork education: Value and purpose'. American Journal of Occupational Therapy, 63, 821-822. https://doi.org/10.5014/ajot.63.6.821

Bonello, M. (2001) 'Perceptions of fieldwork education in Malta: Challenges and opportunities'. Occupational Therapy International, 8 (1), 17-33 https://doi.org/10.1002/oti.129

CAOT (Canadian Association of Occupational Therapists) (2012) Association of Canadian Occupational Therapy University Programs \& Canadian Association of Occupational Therapists Position Statement: Professional responsibility in fieldwork education in occupational therapy. [online] available from https://www.caot.ca/pdfs/positionstate/fieldwork\%20education\%20\%20Position\%20Stat ement\%20Final\%202012.pdf [19 July 2016]

$\mathrm{CIHI}$ (Canadian Institute for Health Information) (2013) Occupational Therapist Database Manual, Version 3.0 [online] Available from https://www.cihi.ca/en/otdb dd v2 en.pdf [20 July 2016]

Christie, B.A., Joyce, P.C., and Moeller, P.L. (1985) 'Fieldwork experience, Part I: Impact on practice preference'. American Journal of Occupational Therapy, 39 (10), 671-674 https://doi.org/10.5014/ajot.39.10.671

Currie, L.M., Wolff, A.C., Mickelson, G., and Chamberlin, C. (2015). Placements for Learners: Assessing Capacity and Effectiveness of Clinical Sites (PLACES) - Final Report. Prepared for the Michael Smith Foundation for Health Research. Vancouver, BC. [online] Available from http://www.msfhr.org/placements-learners-assessing-capacityand-effectiveness-clinical-sites-places-study[16 May 2016]

Dillman, D.A., Smyth, J.D., and Christian, L.M. (2014) Internet, Mail and Mixed-mode Surveys: The Tailored Design Method. 4th edn. Hoboken, NJ: Wiley

Ford, K., Courtney-Pratt, H., Marlow, A., Cooper, J., Williams, D., and Mason, R. (2016) 'Quality clinical placements: The perspectives of undergraduate nursing students and their supervising nurses'. Nurse Education Today, 37, 97-102 https://doi.org/10.1016/i.nedt.2015.11.013

Hall, M., McFarlane, L.-A., and Mulholland, S. (2012) 'Positive clinical placements: Perspectives of students and clinical educators in rehabilitation medicine'. International Journal of Therapy and Rehabilitation, 19 (10), 549-556 https://doi.org/10.12968/ijtr.2012.19.10.549

Hummell, J. (1997) 'Effective fieldwork supervision: Occupational therapy student perspectives'. Australian Occupational Therapy Journal, 44 (4), 147-157 https://doi.org/10.1111/j.1440-1630.1997.tb00769.x

Kirke, P., Layton, N., and Sim, J. (2007) 'Informing fieldwork design: Key elements to quality in fieldwork education for undergraduate occupational therapy students'. Australian Occupational Therapy Journal, 54 (s1), S13-S22 https://doi.org/10.1111/i.14401630.2007.00696.x

Mulholland, S., Derdall, M., and Roy, B. (2006). 'The student's perspective on what makes an exceptional practice placement educator'. British Journal of Occupational Therapy, 69 (12), 567-571 https://doi.org/10.1177/030802260606901206 
Mulholland, S. and Hall, M. (2013) 'The influence of environment on the fieldwork experience: Exploring interprofessional student perspectives'. Work: A Journal of Prevention Assessment \& Rehabilitation, 44 (3), 345-354 doi:10.3233/WOR-121511

Rodger, S., Fitzgerald, C., Davila, W., Millar, F., and Allison, H. (2011) 'What makes a quality occupational therapy practice placement? Students' and practice educators' perspectives'. Australian Occupational Therapy Journal, 58 (3), 195-202 https://doi.org/10.1111/j.1440-1630.2010.00903.x

Skaalvik, M.W., Normann, H.K., and Henriksen, N. (2011) 'Clinical learning environment and supervision: Experiences of Norwegian nursing students - a questionnaire survey'. Journal of Clinical Nursing, 20 (15-16), 2294-2304 https://doi.org/10.1111/i.13652702.2011.03727.x

Sloggett, K., Kim, N., and Cameron, D. (2003) 'Private practice: Benefits, barriers and strategies of providing fieldwork placements'. Canadian Journal of Occupational Therapy, 70 (1), 42-50 https://doi.org/10.1177/000841740307000106

Taylor, C., Angel, L., Nyanga, L., and Dickson, C. (2016) 'The process and challenges of obtaining and sustaining clinical placements for nursing and allied health students'. Journal of Clinical Nursing, 26 (19-20), 3099-3110 https://doi.org/10.1111/jocn.13658

Thomas, Y., Dickson, D., Broadbridge, J., Hopper, L., Hawkins, R., Edwards, A., and McBryde, C. (2007) 'Benefits and challenges of supervising occupational therapy fieldwork students: Supervisors' perspectives'. Australian Occupational Therapy Journal, 54 (s1), S2-S12 https://doi.org/10.1111/i.1440-1630.2007.00694.x

Thomson, R., Docherty, A., and Duffy, R. (2017) 'Nursing students' experiences of mentorship in their final placement'. British Journal of Nursing, 26 (9), 514-521 https://doi.org/10.12968/bjon.2017.26.9.514

WFOT (World Federation of Occupational Therapists) (2016) Minimum Standards for the Education of Occupational Therapists. Available from http://www.wfot.org/Store/tabid/61/CategorylD/1/ProductID/55/Default.aspx [1 August 2017] 


\section{Appendix A \\ Quality of Occupational Therapy Fieldwork Experience Instrument}

\section{Definitions:}

For the purposes of this survey, the following terms are used.

Educational program - the occupational therapy educational institution

Organisation - where the fieldwork experience is taking place

Fieldwork educator - occupational therapists who provide primary supervision during fieldwork placements.

Student - individual who is enrolled in an accredited occupational therapy program

Fieldwork - involves students gaining experiential learning experience in various settings that helps students learn the necessary skills, attitudes and knowledge required to be a safe, and effective occupational therapist. Such services are under general direction and supervision of practising professional staff of the organisation (e.g. occupational therapists).

Manager - patient-care coordinator or other managerial role

Patient - an individual seeking professional services of the occupational therapist. Patient is synonymous with client and consumer.

Practice setting - the context or environment in which occupational therapy care is provided. Practice setting is synonymous with clinical setting, hospital, agency, rehabilitation center, child development center, school etc.

N/A - not applicable.

\section{Instructions:}

The following questions have been designed to measure the quality of the occupational therapy fieldwork learning experience within British Columbia, Canada.

Please select the statement that most closely reflects your opinion:

(Note: please consider only your primary place of employment when responding to survey questions)

\begin{tabular}{|cl|c|c|c|c|c|c|}
\hline Reflecting on your settings provision of fieldwork... & $\begin{array}{c}\text { Strongly } \\
\text { Disagree }\end{array}$ & Disagree & Neutral & Agree & $\begin{array}{l}\text { Strongly } \\
\text { Agree }\end{array}$ & N/A \\
\hline 1. & Fieldwork educators are easy to approach & 1 & 2 & 3 & 4 & 5 & \\
\hline 2. & $\begin{array}{l}\text { Students are encouraged to take part in the } \\
\text { discussion during shift report/patient care } \\
\text { rounds }\end{array}$ & 1 & 2 & 3 & 4 & 5 & \\
\hline 3. & $\begin{array}{l}\text { Manager is supportive of those in the role of } \\
\text { fieldwork educator }\end{array}$ & 1 & 2 & 3 & 4 & 5 & \\
\hline 4. & $\begin{array}{l}\text { Students are made to feel comfortable when } \\
\text { they start each day }\end{array}$ & 1 & 2 & 3 & 4 & 5 & \\
\hline 5. & $\begin{array}{l}\text { Fieldwork educators are capable of supporting } \\
\text { students to meet their learning goals }\end{array}$ & 1 & 2 & 3 & 4 & 5 & \\
\hline
\end{tabular}




\begin{tabular}{|c|c|c|c|c|c|c|}
\hline 6. & $\begin{array}{l}\text { The manager regards the fieldwork educator } \\
\text { as a key resource }\end{array}$ & 1 & 2 & 3 & 4 & 5 \\
\hline 7. & $\begin{array}{l}\text { There is mutual interaction in the learning } \\
\text { relationship between fieldwork educator and } \\
\text { students }\end{array}$ & 1 & 2 & 3 & 4 & 5 \\
\hline 8. & The manager is a team member & 1 & 2 & 3 & 4 & 5 \\
\hline 9. & $\begin{array}{l}\text { Fieldwork educators help students bridge the } \\
\text { theory-practice gap }\end{array}$ & 1 & 2 & 3 & 4 & 5 \\
\hline 10. & $\begin{array}{l}\text { Fieldwork educator and other team members } \\
\text { are positive role models for occupational } \\
\text { therapy }\end{array}$ & 1 & 2 & 3 & 4 & 5 \\
\hline 11. & $\begin{array}{l}\text { Feedback from the fieldwork educator } \\
\text { contributes to learning }\end{array}$ & 1 & 2 & 3 & 4 & 5 \\
\hline 12. & $\begin{array}{l}\text { The efforts of individual fieldwork educators are } \\
\text { appreciated by the manager }\end{array}$ & 1 & 2 & 3 & 4 & 5 \\
\hline 13. & $\begin{array}{l}\text { The occupational therapy philosophy is clearly } \\
\text { defined }\end{array}$ & 1 & 2 & 3 & 4 & 5 \\
\hline 14. & $\begin{array}{l}\text { Fieldwork educators integrate theoretical } \\
\text { knowledge in their everyday practice of } \\
\text { occupational therapy }\end{array}$ & 1 & 2 & 3 & 4 & 5 \\
\hline 15. & $\begin{array}{l}\text { Fieldwork educators are generally interested in } \\
\text { working with students }\end{array}$ & 1 & 2 & 3 & 4 & 5 \\
\hline 16. & $\begin{array}{l}\text { Fieldwork educators take an active role in } \\
\text { support student learning through various } \\
\text { teaching strategies (e.g. weekly reflections, } \\
\text { theoretical and practical learning) }\end{array}$ & 1 & 2 & 3 & 4 & 5 \\
\hline 17. & $\begin{array}{l}\text { Fieldwork educators make an effort to get to } \\
\text { know the students }\end{array}$ & 1 & 2 & 3 & 4 & 5 \\
\hline 18. & $\begin{array}{l}\text { Fieldwork educators encourage more } \\
\text { independence as students' skills increase }\end{array}$ & 1 & 2 & 3 & 4 & 5 \\
\hline 19. & There is a good learning environment & 1 & 2 & 3 & 4 & 5 \\
\hline 20. & $\begin{array}{l}\text { Students are satisfied with the supervision they } \\
\text { receive }\end{array}$ & 1 & 2 & 3 & 4 & 5 \\
\hline 21. & $\begin{array}{l}\text { Fieldwork educators are able to provide their } \\
\text { expertise to the team }\end{array}$ & 1 & 2 & 3 & 4 & 5 \\
\hline 22. & $\begin{array}{l}\text { Fieldwork educators are aware of students' } \\
\text { learning objectives before students arrive }\end{array}$ & 1 & 2 & 3 & 4 & 5 \\
\hline 23. & There is a spirit of solidarity among the team & 1 & 2 & 3 & 4 & 5 \\
\hline 24. & $\begin{array}{l}\text { Fieldwork educators inform students of } \\
\text { possible learning experiences }\end{array}$ & 1 & 2 & 3 & 4 & 5 \\
\hline 25. & $\begin{array}{l}\text { Fieldwork educators have the opportunity to } \\
\text { attend preceptor/mentor training }\end{array}$ & 1 & 2 & 3 & 4 & 5 \\
\hline 26. & $\begin{array}{l}\text { There is a well-defined communication process } \\
\text { between the fieldwork educator and the } \\
\text { education program }\end{array}$ & 1 & 2 & 3 & 4 & 5 \\
\hline
\end{tabular}

